\title{
UNIVERSAL PERMISSIVE JURISDICTION FOR THE VIOLATION OF COMMON ARTICLE 3 OF THE GENEVA CONVENTIONS FOR THE PROTECTION OF THE VICTIMS OF WAR OF 12 AUGUST 1949*
}

\author{
Takhmina Karimova*
}

\section{INTRODUCTION}

It has been estimated that more than 250 conflicts of a non-international character, internal conflicts, and tyrannical regime victimization have occurred since World War II. ${ }^{1}$ While the law applicable to international conflicts has been widely accepted and comprises the necessary enforcement mechanisms, the law of noninternational armed conflicts remains limited to common Article 3 of the Geneva Conventions for the protection of the victims of war of 12 August 1949, and to the Additional Protocol II relating to the protection of victims of non-international armed conflicts of 8 June 1977. Provisions mentioned indeed represent a minimum set of standards and do not encompass the notion of "grave breaches" since it was viewed that the grave breaches provisions would constitute an encroachment on state sovereignty. ${ }^{2}$

However, the recent developments in international humanitarian law and international criminal law have changed the situation; new approaches are evolving in order to put an end to the long existent impunity ${ }^{3}$ of the perpetrators of the most heinous crimes committed in internal conflicts. When, due to the failure of the domestic structure, to political unwillingness or to the weakness of a state ${ }^{4}$ the perpetrators go unpunished, the concept of universal jurisdiction offers the means

\footnotetext{
* This article won the Sata International Law Prize for 2003.

** Intern at the International Criminal Court in The Hague; LL.M. Essex University, UK, 2003.

${ }^{1}$ C. Bassiouni, "Universal Jurisdiction for international crimes: historical perspectives and contemporary practice”, 42 Va.J.Int'l.L 1., 2001 (Lexis-nexis).

2 T. Graditzky, "Individual criminal responsibility for the violations of humanitarian law committed in non-international armed conflicts", IRRC, No. 322 (1998), 29-56 at 30.

3 J. Dugard, "Bridging the gap between human rights and humanitarian law: punishment of offenders, IRRC, No. 324 (1998), 445-453 at 447.

${ }^{4}$ Bassiouni, n. 1.
}

Asian Yearbook of International Law, Volume 10 (B.S. Chimni et al., eds.)

(C) 2005 Koninklijke Brill NV. Printed in The Netherlands, pp. 125-143. 
of repression of serious violations of the law applicable in internal armed conflicts. ${ }^{5}$ The major challenge in this sphere would be the determination of whether international law as it stands today gives states the authority to prosecute and try ${ }^{6}$ those in charge of the internal atrocities or, in other words, whether the notion of universal jurisdiction extends to the violation of common Article 3 of the Geneva Conventions, and if it does, what form of jurisdiction it takes. The work will focus on jurisdiction over violations of common Article 3 as Protocol II, due to the fact that its higher threshold of applicability rarely comes into effect and, therefore, a universally recognized norm such as Article 3 remains a primary source of the law applicable in noninternational armed conflicts. ${ }^{7}$ The first section of the present work considers the concept of universal jurisdiction in the first instance, its scope, and the forms it may take. This is essential in order to give a general overview of what universal jurisdiction is meant to be and its forms, in particular universal permissive jurisdiction. The second section reflects on the content of Article 3 and its specific provisions: the core of the main question whether the violation of these provisions would give rise to universal permissive jurisdiction. Such an analysis will be made in the third section; specifically, it will explore the existing opinio juris and state practice that evidence criminalization of Article 3, i.e., whether it can be assumed that an international custom has been formed to provide a universal mechanism of enforcement of the Article. Lastly, the fourth section aims at briefly describing the implications of the Rome Statute of International Criminal Court on common Article 3, particularly the role of the Rome Statute with regard to criminalization in Article 3 of the Geneva Conventions.

\section{UNIVERSAL JURISDICTION}

\subsection{General aspects of Jurisdiction}

The term 'jurisdiction' can have different meanings, yet it is generally accepted that it embraces the "power to prescribe, adjudicate and enforce". ${ }^{8}$ The power to prescribe refers to legislative jurisdiction, the environment for making the law applicable to actors, events, or things. ${ }^{9}$ The authority of the state to subject certain actors or things to the processes of its judicial or administrative tribunals, ${ }^{10}$ i.e., the application of the law, constitutes adjudicatory jurisdiction. Lastly, the power to take action to compel the actors to comply with laws and to redress non-compliance is called 'enforcement jurisdiction'. Bassiouni suggests that these powers derive from the

5 Graditzky, n. 2, at 30.

6 Ibid.

7 A.G. Peterson, "Order out of the chaos: domestic enforcement of the law of armed conflict", 171 Mil.L.Rev. (2002), 1-91, at 17.

8 Bassiouni, n. 1, f. 31.

9 K.C. Randall, Universal jurisdiction under international law, 66 Tex.L.Rev., 1988 (Lexis-nexis).

10 Ibid. 
principle of state sovereignty. where legislative jurisdiction is closely linked with the sovereignty of the state, while adjudicative and enforcement jurisdiction may not necessarily be connected with sovereignty as this jurisdiction can directly affect jurisdictional conflicts between the states; Bassiouni sees the best way to resolve any such conflict as being by means of extraterritorial jurisdiction in the case of valid legal nexus. ${ }^{11}$ International law indeed provides several principles as legal bases for such an extraterritorial jurisdiction.

These include the principle of territoriality, under which the jurisdiction is claimed by the court where the offence is committed, ${ }^{12}$ through the nationality or active personality principle, which gives jurisdiction to the state over the crimes committed by the person having the same nationality as that state, ${ }^{13}$ through the passive personality principle, i.e., when the victim is a national of the state, the protective principle provides jurisdiction over the crimes affecting the security of state, ${ }^{14}$ and lastly, through the universality principle. The principles listed, with the exception of the universality principle, are limited; that is, for jurisdiction to be claimed, there is a necessity to establish a link, either considering the act that has been committed in which case principle of territoriality is exercised - or the offender, justified by the nationality principle, or with the victim, under the passive personality principle, or else a link with the interests of a state, as provided by the protective principle.

\subsection{Universal jurisdiction: concept and scope}

The foremost of the significant features of the universality principle, unlike the other principles of jurisdiction, lies in the absence of any requirement of any kind of link between the act committed and the state exercising jurisdiction; in other words, "universal jurisdiction transcends national sovereignty". ${ }^{15}$ Being an exception to the traditional forms of jurisdiction, it provides that "every state has jurisdiction over a limited category of offences generally recognized as of universal concern, regardless of the situs of offence and the nationality of the offender and the offended". ${ }^{16}$ As a consequence, states have the authority to prosecute a crime without the presence of any connection between the place of the crime committed, the perpetrator's nationality, the victim's nationality, and the enforcing state. ${ }^{17}$

International conventional and customary law are primary sources of international criminal law. Conventional law is deemed to be more easily adaptable to the require-

11 Bassiouni, n. 1, f. 36.

${ }^{12}$ M. Hudson, “Case of SS 'Lotus'”, World Court Reports, Vol. II: 1927-1932, New York: Oceana

Publishers, 1969, at 20.

${ }_{13}$ ICRC fact sheet on National Enforcement of International Humanitarian Law, http://www.icrc.org/ Web/eng/siteeng0.nsf/iwpList74/39587781F62FF7F4C1256B66005C8CF1 (accessed 27.02.2003)

${ }_{14}^{14}$ I. Brownlie, Principles of Public International Law, Oxford: Clarendon Press, 1998, at 307.

15 Bassiouni, n. 1, f. 54.

16 Randall, n. 9.

17 Ibid. 
ments of legality, the principles of nullum crimen sine lege and nulla poena sine lege; however, this aspect does not diminish the status of customary law as a substantial source. ${ }^{18}$ Thus, the applicability of universal jurisdiction can be invoked with reference to 1) national legislation; 2) conventional law determining whether there are legal norms providing application of universal jurisdiction. ${ }^{19}$ For example, the United Nations Convention on the Law of the Sea grants the states the right to seize any pirate ship or aircraft in any place outside their jurisdiction, ${ }^{20}$ and 3 ) as has already been mentioned, customary law.

Among the 27 categories of crimes in international law evidenced by 276 conventions, only a few of them provide universal jurisdiction. ${ }^{21}$ Universal jurisdiction cannot therefore be exercised in relation to any and all crimes, but only in respect of particular crimes; it is at present universally recognized that piracy, slavery, war crimes, crimes against humanity, genocide, apartheid and torture are based on customary and conventional international law and, as such, are "construed as reflecting universal jurisdiction". ${ }^{22}$

An assessment of different theories of universal jurisdiction by Bassiouni leads him to the conclusion that the standpoint of each theory is found in the assertion that there are certain commonly shared values in and interests of the international community that necessitate the expansion of enforcement mechanisms to counter serious breaches of these values; there also exists an assumption that the enforcement of these mechanisms will provide deterrence, world order, peace and justice. ${ }^{23}$ Taking this further, Randall points out that every state has an interest in exercising jurisdiction over the crimes that have been universally condemned ${ }^{24}$ and which violate norms of international concern. As a consequence, a state exercises actio popularis against persons who are hostis humanis generis and thus acts as a "surrogate for the international community". ${ }^{25}$ Broomhall suggests that universal jurisdiction "fills the gap left where other more basic doctrines of jurisdiction provide no basis for the national proceedings". ${ }^{26}$ Thus, this point is essential with regard to the suppression of breaches of common Article 3, as there is indeed no mechanism in force under the conventional law. Where there is a risk that the domestic enforcement system may be ineffective, the universality principle acts as a safety net in the prosecution of crimes of international concern.

18 Bassiouni, n. 1.

19 Ibid.

20 UN Convention on the Law of the Sea of 1982, Art. 105.

21 Bassiouni, n. 1.

22 Ibid.

23 Ibid.

24 Randall, n. 9.

25 Bassiouni, n. 1.

26 B. Broomhall, "Towards the development of an effective system of universal jurisdiction for crimes under international law", 35-2 N.Eng.L.Rev. 400 http://www.nesl.edu/lawrev/Vol35/35-2/ broomhall.pdf (accessed 02.03.2003). 


\subsection{Forms of universal jurisdiction}

While this is not a subject of uniformity, there exist assertions among the scholars dealing with the forms of universal jurisdiction known as mandatory and permissive universal jurisdiction; these assertions are founded on the logic of the interpretation of the "must and may" possibilities of actions taken by states. Therefore, when universal jurisdiction is permissive, a state has the right and "may" exercise the authority to prosecute or try perpetrators. When the jurisdiction is mandatory, it is more than a mere right: rather, it is an obligation of the state to prosecute and try the offenders. The famed formula for the mandatory universal jurisdiction reads aut dedere aut judicare, i.e., either extradite or punish.

It is claimed that the distinction between the mandatory and permissive jurisdictions draws a parallel between customary law and conventional law. ${ }^{27}$ Treaty law usually defines the crime and obliges the states parties to investigate and prosecute, or otherwise extradite the perpetrators to a state willing to do so. An appropriate example is the "grave breach" provisions of the Geneva Conventions of 1949. According to the relevant article of each of the conventions a state must search for the alleged offenders and consider either bringing them to its national courts or handing them over to another state party. ${ }^{28}$ There is a speculation that when the language of the treaty is based on the aut dedere aut judicare formula, the jurisdiction is not truly "universal"; it is further maintained that in such cases the treaty more closely resembles a regime of "jurisdictional rights and obligations arising among a close set of states parties". ${ }^{29}$

In contrast with the mandatory form, the permissive universal jurisdiction mainly originates in customary international law; therefore, there is no ground to assert that states are required to exercise jurisdiction under customary international law.

An example of permissive jurisdiction can be found in the law of armed conflicts, where there is a clear requirement to repress grave breaches; Article 86 of Additional Protocol I states that "the high contracting parties shall repress grave breaches, and take measures necessary to suppress all other breaches of the Conventions or the Protocol which result from a failure to act when in duty to do so"30 (emphasis added). Here, a duty can be revealed in the wording of "shall", and a right that is permission under the wording of "take measures necessary". There is, therefore, no obligation as such. Hence, with respect to war crimes that do not constitute grave breaches, the states "may" exercise universal jurisdiction in order to repress the violations.

Having discussed some relevant issues on universal jurisdiction, it is now necessary to come closer to the main subject of this work and to illustrate the rationale for examining the universal permissive jurisdiction applicable to the violation of

27 Ibid., 401.

28 Geneva Convention Relative to the Treatment of Prisoners of War of 12 August 1949, Art. 129.

29 Broomhall, n. 26, at 401 .

30 Protocol Additional to the Geneva Conventions of 12 August 1949 relating to the Protection of the Victims of International Armed Conflicts, Art. 86. 
common Article 3. Since neither common Article 3 nor Protocol II contain provisions requiring states to punish serious violations of the law of internal conflicts, there appears to be no ground to invoke universal jurisdiction under international conventional law. ${ }^{31}$ However, due to the recent changes in international law (which will be analysed later in greater detail), there are bases for ascertaining that serious violations of Article 3 are punishable: if a crime is condemned and found as criminal in international conflicts, there is no reason why it should not be condemned in the context of internal conflicts. ${ }^{32}$ These grounds are viewed as being based on customary international law. Before resorting to polemics on customary law, first of all it is for reasons of comprehensibility necessary to illustrate the context of Article 3 itself.

\section{COMMON ARTICLE 3 OF THE GENEVA CONVENTIONS OF 1949}

Article 3 appears in the text of each of the Geneva Conventions of 1949 and contains provisions that are applied in the armed conflicts of non-international character. The article "sets forth the minimum protections and standards of conduct to which the state and its armed opponents must adhere". ${ }^{33}$

Under the provisions of Article 3 each party to the conflict shall be bound to apply, as a minimum, the following provisions:

1) Persons taking no active part in the hostilities, including members of armed forces who have laid down their arms and those placed hors de combat by sickness, wounds, detention, or any other cause, shall in all circumstances be treated humanely, without any adverse distinction founded on race, colour, religion, faith, sex, birth or wealth or any other similar criteria.

To this end the following acts are and shall remain prohibited:

a) violence to life and person, in particular murder of all kinds, mutilation, cruel treatment and torture;

b) taking of hostages;

c) outrages upon personal dignity, in particular humiliating and degrading treatment;

d) passing of sentences and carrying out executions without previous judgement pronounced by a regularly constituted court, affording all judicial guarantees which are recognized indispensable by civilized people. ${ }^{34}$

${ }^{31}$ M. Griffin, "Ending the impunity of perpetrators of human rights atrocities: a major challenge for international law in the $21^{\text {st }}$ century", IRRC, No. 838, 369-389, at 372.

${ }^{32}$ C. Enache-Brown and A. Fried, "Universal crime, jurisdiction and duty: the obligation of aut dedere aut judicare in international law", 43 McGillL.J.(1998), 613 (Lexis-nexis).

${ }^{33}$ S. Ratner, "International v. internal armed conflict", http://www.crimesofwar.org/thebook/intl-vsinternal.html (accessed 13.03.2003).

${ }^{34}$ Geneva Convention III, n. 28, Art. 3. 
Common Article 3 sets out the fundamental principles of humanity that apply in internal armed conflict and is binding on each party to the conflict, including the insurgent forces. ${ }^{35}$ However, the binding nature of the provisions does not presume a recognition of the status of the insurgents.

Article 3 was, rather, meant only to establish fundamental humanitarian standards, not to define status. ${ }^{36}$ The International Court of Justice in the Nicaragua case has determined that Article 3 contains the rules that "constitute a minimum yardstick" applicable even in international conflicts. ${ }^{37}$ Notwithstanding the minimum requirements and the lack of status recognition, the parties very often do not apply these standards.

When discussing a norm within the framework of international law, the issue of customary rules becomes relevant; it is accepted that Article 3 has reached the status of customary international law. ${ }^{38}$ The International Criminal Tribunal for the former Yugoslavia (hereinafter the ICTY) held that the law governing internal conflicts developed on two levels: in customary and in conventional law, and some treaty rules have become customary, which was for the most part true in relation to common Article 3. Furthermore, the tribunal confirmed its position by referring to the authoritative decision held by the ICJ in Nicaragua $v$. United States of America (a case concerning the military and paramilitary activities of the US in and against the interests of Nicaragua). ${ }^{39}$

In considering the provisions regulating conflicts of internal character, one point should be mentioned: that the conflict in question is presumably limited to the area within the frontiers of a particular state, which has sovereign authority over its territory. Consequently, offences committed within the boundary of a particular state fall under the national jurisdiction of that state. Most of the violations of the rules of war also "violate rules of general criminal law namely those relating to homicide, bodily assault, or other offences against physical or sexual integrity, offences against property". 40

Accordingly, it would not be incorrect to assume that violations of the law applicable to internal conflicts, specifically of Article 3, may be considered a crime under the general criminal law provisions of the state concerned. ${ }^{41}$ Thus, domestic mechanisms conduct the suppression of breaches of Article 3. However, experience shows that most of the violations - on the part of the government, for instance -

\footnotetext{
35 J. Pictet, The Geneva Conventions of 12 August 1949: Commentary, Vol. I, ICRC, 1952, at 38-61.

${ }^{36}$ Peterson, n. 7, at 18.

${ }^{37}$ Nicaragua $v$ USA Military, ICJ Rep. 1986, 14, at 114, para. 218. http://www.icjcij.org/icjwww/ icases/inus/inus_ijudgment/inus_ijudgment_19860627.pdf (accessed 06.03.2003).

${ }_{38}$ Prosecutor v. Tadic, case IT-94-1-AR72, Appeal on Jurisdiction (2 October 1995), para. 98; Prosecutor v. Delalic et al., case IT-96-21, judgment (16 November 1998) http://www.un.org/icty/ celebici/trialc2/judgement/index.htm ; Prosecutor v. Akayesu, case ICTR-96-4 (2 September 1998), para. $608 \mathrm{http}: / / \mathrm{www} . i c t r . o r g / w w w r o o t / d e f a u l t . h t m$ (accessed 07.03.2003).

39 Prosecutor v. Tadic, n. 38, para. 98.

40 M. BOTHE, "War crimes in non-international armed conflicts" in Y. Dinstein and M. Tabory (eds.), War Crimes in International Law, Martinus Nijhoff Publishers, 1996, 293-305, at 295.

41 Ibid.
} 
will be justified by the excuse of the maintenance of the rule of law and order required by the legal system of that state. ${ }^{42}$ It is therefore argued that "there is no moral justification ... for treating the perpetrators of atrocities in internal conflicts more leniently than those engaged in international wars"; ${ }^{43}$ universal permissive jurisdiction can act as a substitute for an enforcement mechanism.

From the text of Article 3 it is obvious that most of its provisions overlap with those of international human rights law provisions, and that violation of the prohibitions can amount to crimes against humanity or genocide; as a result, apparently, crimes committed in the context of internal conflicts will not go unpunished. Nonetheless, due to difficulties in definition and other requirements, such as proof of the systematic or deliberate nature of the crime, ${ }^{44}$ some of the killings or other serious violations can fall outside the scope of the crimes mentioned. For example, according to Article 7 of the Rome Statute for International Criminal Court, an act can constitute a crime against humanity if it is proved that the act committed was a part of widespread or systematic (emphasis added) attack against any civilian population with the knowledge of the attack, ${ }^{45}$ while in order to establish a violation of Article 3 there is no need to ascertain the systematic or widespread character of the crime.

Thus, the next issue to be addressed is the determination in what circumstances universal jurisdiction is applicable since there is a risk that a domestic legal system, out of policy or other considerations, fails to respond accurately to the violation of common Article 3 - the minimum humanitarian standards applicable in internal conflicts. In relation to universal permissive jurisdiction, it must be noted that we should hypothetically assume, pending a thorough discussion, that for such jurisdiction to be exercised in the absence of relevant treaty provision we must determine the existence of customary international law criminalizing breaches of Article 3.

\section{CRIMINALIZATION OF COMMON ARTICLE 3 UNDER CUSTOMARY INTERNATIONAL LAW AND UNIVERSAL JURISDICTION}

The process of a rule acquiring the status of customary law is uneven. ${ }^{46}$ Nonetheless, "international humanitarian law has developed faster since the beginning of atrocities in the former Yugoslavia than in half-century since the Nuremberg tribunals and the adoption of Geneva Conventions for the protections of victims of war of

\footnotetext{
42 Ibid.

43 Ibid. 238.

44 T. Meron, "International criminalization of internal atrocities", in T. Meron (ed.), War Crimes Law Comes of Age, Oxford: Clarendon Press, 1998, 228-262, at 234.

45 Rome Statute of ICC (A/CONF.183/9), entered into force 1 July 2002 http://www.icc.org (accessed 13.03.2003) Art. 7.

46 Peterson, n. 7, at 26.
} 
12 August of $1949 "{ }^{47}$ In this respect the practice of the International Criminal Tribunal for the former Yugoslavia is a particularly valuable source of assessment of Article 3 and its criminalization (i.e., the prosecution of breaches of Article 3 under international law).

It is a tenet of international law that in order for a rule to become a customary norm two elements are essential: state practice and opinio juris ${ }^{48}$ the latter is believed to be a conviction held by states that a certain form of conduct is required under international law. ${ }^{49}$ The Tribunal in Appeal on Jurisdiction (Tadic case) has pointed out that in relation to the establishment of the general practice in such an area as the law of internal armed conflict, it is difficult to "pinpoint the actual behaviour of the troops in the field for the purpose of establishing whether they in fact comply with, or disregard, certain standards of behaviour"; ${ }^{50}$ the court has reasoned its position by lack of access to the theatre of military operations, a lack of information, etc. and thus "on account of the inherent nature of this subject-matter, reliance must primarily be placed on such elements as official pronouncements of States, military manuals and judicial decisions", 51 i.e., opinio juris. The position of the tribunal on this question has been contested; the counterargument was that the training, education, and disciplining of a state's soldiers are also a reliable evidence of state practice. ${ }^{52}$ Another interesting position concerning the court's approach was brought forward by Theodor Meron. He observes in particular that the tribunal used statements as an evidence of both practice and opinio juris, and expresses the view that the tribunal relied mainly on human rights methodology, whereas opinio juris is deemed to compensate for insufficiency of practice. ${ }^{53}$

\subsection{Opinio juris}

The International Committee of the Red Cross (hereinafter the ICRC) in its comment on the draft statute for the Yugoslavia tribunal admitted that "in accordance with the International Humanitarian Law as it stands today, the idea of war crimes is limited to the situations of international armed conflict", ${ }^{54}$ furthermore, in the course of establishing the ICTY it was perceived that Article 3 and Protocol II "were not the rules of international humanitarian law which are beyond doubt part of

\footnotetext{
47 T. Meron, "War crimes law for the twenty-first century: the law of armed conflict into the next millennium", in Schmitt and Green, US Naval War College International Studies, Vol. 71 (Rhode Island: Newport, 1998), 325-335, at 326.

${ }^{48}$ P. Malanczuk, Akehurst's Modern Introduction to International Law , London: Routledge, 2001, at 44 .

49 Ibid.

${ }^{50}$ Prosecutor v. Tadic, n 38, para. 99.

51 Ibid

52 Peterson, n. 7, at 46.

53 T. Meron, "The continuing role of custom in the formation of international humanitarian law",

T. Meron (ed.), War Crimes Law Comes of Age, Oxford: Clarendon Press, 1998, 262-278, at 264.

${ }^{54}$ Meron, n. 44, at 236.
} 
customary international law". ${ }^{55}$ Yet long before, the International Court of Justice had not only established the customary status of common Article 3 in the Nicaragua case, but held that Article 3 should be considered in light of Article 1 of the Geneva Conventions given that states are obliged to "respect" and "ensure respect" of the conventions. ${ }^{56}$ In view of the latter the obligation to respect implies penal measures to suppress war crimes. ${ }^{57}$

In contrast to the opinion of the International Court of Justice, the political will of the international community as expressed by some representatives of leading countries was in favour of the criminalizing norms applicable in internal conflicts. In particular, the US permanent representative to the United Nations stated that the US understanding of the "laws and customs of war" in Article 3 of the ICTY Statute are such that they "include all obligations under humanitarian law agreements in force in the territory of the former Yugoslavia at the time the acts were committed, including common Article 3 of 1949 Geneva Conventions". ${ }^{58}$ Statements to a similar effect were made by the representatives of a number of other states. ${ }^{59}$ It is therefore concluded that these statements entail the existence of universal jurisdiction. ${ }^{60}$

In looking for the sources of opinio juris, the Security Council resolutions addressing internal conflicts should not be ignored. For instance, Security Council resolution 794 concerning Somalia "strongly condemns all violations of international humanitarian law ... and affirms that those who commit or order the commission of such acts will be individually held responsible". ${ }^{61}$ The Security Council resolutions in relation to the conflicts in Rwanda also contain similar provisions and stress the need to take effective measures to bring to justice those in charge of the commission of the crimes. ${ }^{62}$ Hence, the resolutions adopted by the Security Council constitute evidence that the Security Council regards as an established principle of international law the criminal responsibility of the individuals who have committed or ordered to be committed those violations of international humanitarian law in the context of internal conflicts. ${ }^{63}$

The developments in the field of the law applicable in internal armed conflicts occurred mainly owing to the establishment and further proceedings of International

\footnotetext{
${ }^{55}$ Secretary General's Report to the Security Council on the establishment of the ICTY, UN Doc. S/25704, 3 May 1993, para. 34, cited in Prosecutor v. Akayesu, para. 608. 2 September 1998. http:// www.ictr.org/wwwroot/default.htm (accessed 06.03.2003).

${ }^{56}$ Nicaragua v USA, n 38, at 114, para. 220.

57 Meron, n. 44, at 251.

58 UN Doc. S/PV.3217 (25 May,1993), at 15, cited in John R.W.D. Jones, The Practice of International Criminal Tribunals for the Former Yugoslavia and Rwanda, Irvington-on-Hudson, NY: Transnational Publishers, Inc., at 35.

59 Ibid.

${ }^{60}$ Graditzky, n. 2, at 35.

${ }^{61}$ UN Doc. S/RES/794 (1992), 47 U.N. SCOR, at 63, http://www1.umn.edu/humanrts/peace/docs/ scres794.html (06.03.2003).

${ }^{62}$ UN Doc. S/RES/978 (1995) http://ods-dds-ny.un.org/doc/UNDOC/GEN/N95/054/92/PDF(16.03. 2003).

${ }^{63}$ Graditzky, n. 2, at 49.
} 
Tribunals of the former Yugoslavia and Rwanda when developments in the sphere of the law applicable in internal conflicts were reflected in the decisions of the tribunals. An illustration of some points of its jurisprudence is essential.

The Statute of the ICTY was drafted to deal with the conflict in the territory of the former Yugoslavia as being international in nature, as the offences listed in Articles 2 and 3 of the Statute indicate ${ }^{64}$ nevertheless, it is believed that nothing in the Statute denies the possibility of criminalization of the serious violations of the law of non-international conflicts. ${ }^{65}$ It was mainly the mixed character of the conflict that forced the drafters to draw up the Statute with discretion. The explanation for this cautious approach is that "the Security Council intended that to the extent possible, the subject matter jurisdiction of the International tribunal should extend to both internal and international armed conflicts". ${ }^{66}$ The progressive step taken by the tribunal was an extension of the applicability of article 3 of its Statute. The Appeal Chamber by a majority held that "violations of the laws and customs of war" covered also violations of common Article 3 of the Geneva Conventions of 1949 and other customary rules of internal conflicts. ${ }^{67}$ However, these violations must meet the specific conditions set, in order for Article 3 of the International Criminal Tribunal for former Yugoslavia Statute to be applied:

1) The violation must constitute an infringement of a rule of international humanitarian law;

2) The rule must be customary in nature, or if it belongs to treaty law, the required conditions must be met ...;

3) The violation must be "serious", that is to say, it must constitute a breach of a rule protecting important values, and the breach must involve grave consequences for the victim. Thus, for instance, the fact of a combatant simply appropriating a loaf of bread in an occupied village would not amount to a "serious violation of international humanitarian law";

4) The violation of the rule must entail, under customary or conventional law, the individual criminal responsibility of the person breaching the rule. ${ }^{68}$

In the case of the tribunal for Rwanda and in view of the nature of the conflict which was classified as being of a non-international character, the Security Council elected to take a more "expansive approach to the choice of the applicable law than the one underlying the Statute of the Yugoslav Tribunal, and included within the subject-matter jurisdiction of the Rwanda Tribunal international instruments regardless of whether they were considered part of customary international law or whether they have customarily entailed the individual criminal responsibility of the perpetrators

\footnotetext{
Meron, n. 44, at 231.

Graditzky, n. 2, at 49.

Prosecutor $v$. Tadic, n. 38, para.78.

Ibid. para. 89.

68 Ibid., para. 94.
} 
of the crime. Article 4 of the Statute ... [thus it] for the first time criminalizes [violations of] common Article 3 of the four Geneva Conventions. "69

The International Law Commission, a body set up by the General Assembly for the development of international law, plays an important role in forming legal doctrines in international law, and one of the areas of the work of the International Law Commission has been the Draft code on crimes against the peace and security of mankind. Article 20 of the Draft code deals with war crimes; in particular, paragraph (f) lists as war crimes certain violations of the international humanitarian law applicable in the conflicts of a non-international character. ${ }^{70}$ The enumerated violations are analogous to the context of common Article 3. Furthermore, in the commentary of its Report on the work of its Forty-Eighth session, the International Law Commission considers paragraph (f) significant in the light of the frequency of non-international conflicts, and states that the International Criminal Tribunal for the former Yugoslavia had "reaffirmed" the principle of individual criminal responsibility. ${ }^{71}$ The word "reaffirmed" may imply that it had been already an existing principle prior to the decision and also may imply that the principle is generally recognized.

The Security Council Resolutions, ad hoc tribunals and the International Law Commission stress the establishment of principle of individual criminal responsibility, a significant factor with regard to universal jurisdiction. Present international law prescribes individual criminal responsibility for the serious crimes that are of universal concern. The Draft Code of Crimes against the Peace and Security of Mankind and the Rome Statute of International Criminal Court are worthy of note, listing the crimes widely accepted as being those entailing individual criminal responsibility. Article 2 of the Draft Code provides individual criminal responsibility for aggression, genocide, crimes against humanity, war crimes and crimes against the United Nations and associated personnel, ${ }^{72}$ while Article 1 of the Rome Statute of International Criminal Court emphasizes the purpose of the establishment of the court to exercise jurisdiction over the persons committing the most serious crimes: namely, genocide, crimes against humanity, war crimes and crimes of aggression, with Article 25 laying down individual responsibility for their commission. ${ }^{73}$ Offences listed as international crimes in these authoritative sources encompass the notion of universal jurisdiction; thus, universal jurisdiction and individual criminal responsibility are interrelated elements of the most serious international crimes. It can consequently be assumed that giving rise to individual criminal responsibility in the context of non-international conflicts necessitates recognition of universal jurisdiction and that, accordingly, violations of Article 3 seem to be regarded as war crimes.

${ }^{69}$ Prosecutor v. Akayesu, n. 38, para. 604.

${ }^{70}$ ILC Draft Code of Crimes against Peace and Security of Mankind 1996, art. 20 http://www.un.org/ law/ilc/texts/dcodefra.htm (18.03.2003).

${ }^{71}$ Report of the International Law Commission on the Work of its Forty-Eighth Session, 6 May to 26 July 1996 (A/51/10), http://www.un.org/law/ilc/reports.htm, (accessed 7.03.2003), at 119.

72 ILC Draft Code, n. 70, Art. 2.

73 Rome Statute, n. 45. 


\subsection{Establishment of state practice}

In the field of customary international law the view of what states regard as a rule is not enough to deem it such. Article 38, paragraph (b), of the Statute of the International Court of Justice provides that opinio juris must be confirmed by general state practice. ${ }^{74}$ As mentioned earlier with reference to the Tadic case, the behaviour of the parties in the theatre of military operations is not the only evidence; evidence of state practice can also be found in military manuals and national legislation. Even government statements to the press and international conferences can constitute state practice. $^{75}$

\subsubsection{Military manuals}

The value of the military manuals derives from the fact that these regulate the conduct of the armed forces, who are the primary participants in all kinds of armed conflict. The Appeal Chamber in the Tadic case drew attention to the Military Manual of Germany of 1992, which has included, under the rubric of "grave breaches of the international humanitarian law", "criminal offences" against persons protected by common Article 3, such as "willful killing, mutilation, torture or inhumane treatment including biological experiments, willfully causing great suffering, serious injury to body or health, taking of hostages", as well as "the fact of impeding a fair and regular trial". ${ }^{76}$ In addition to this the Appeal Chamber submits examples of the military manuals of New Zealand in which the violation of common Article 3 is treated as a war crime. The manuals of the United States of America and of Great Britain were placed under scrutiny, as their interpretation of war crimes includes the infringement of common Article $3 .^{77}$ Most military manuals do not draw a distinction regarding the nature of the conflict to which the international humanitarian law is applied, but some recognize the applicability of international humanitarian law to all situations involving armed conflict. ${ }^{78}$

\subsubsection{Domestic legislation}

A recent study carried out by Amnesty International on universal jurisdiction identifies different categories of national legislations, namely, legislations providing universal jurisdiction over the general definition of "war crime" which can be interpreted as also implying crimes committed in internal conflicts; another category comprises

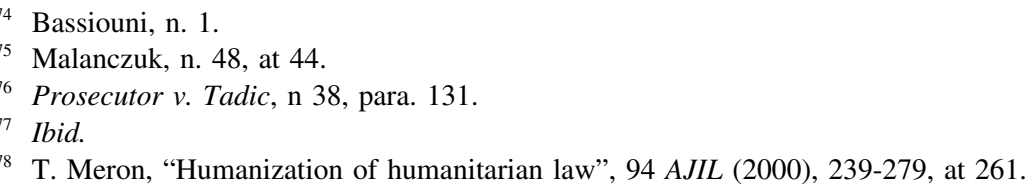


the legislations expressly giving courts the authority to exercise universal jurisdiction over crimes committed in non-international conflicts. ${ }^{79}$

Among the most prominent national legislations criminalizing and providing universal jurisdiction is the Belgian Law of 16 June 1993 regarding the grave breaches of the Geneva Conventions. This law qualifies as "war crimes" violations of specific norms applicable in internal conflicts: Article 2, section 3, lists the offences against protected persons under the Geneva Conventions and Additional Protocols I and II. ${ }^{80}$ Article 7 of the law provides universal jurisdiction; specifically, it states that the Belgian courts do not need to establish their territorial or national link with the perpetrator. ${ }^{81}$ Yet a point is raised that reveals doubts concerning the threshold of internal conflicts. ${ }^{82}$ It is well known that Protocol II puts a higher threshold of applicability than does Article 3. As a consequence, from the context of the Belgian law it is not clear whether there can be grave breaches of Article 3.

The Spanish Penal Code follows the same path as the Belgian legislation by including innovative provisions for criminalizing certain acts committed in armed conflicts of a non-international character. Thus, Article 608 includes in the category of "protected persons" those who are covered by the provisions of Additional Protocol II of 1977. Norms governing violations of the law of internal armed conflicts are grouped under the provisions regulating conflicts generally, which are in their turn classified under the heading of "crimes against [the] international community" ${ }^{83}$

The United States War Crimes Act of 1996 is applicable in situations when the crime is committed by or the victim of the crime is a member of the armed forces or a national of the United States. In comparison with the two previous examples, the context of "war crimes" in this law covers violations of common Article $3 .{ }^{84}$ The inclusion of common Article 3 in war crimes is evaluated as a demonstration "that the United States of America considers criminal accountability for violation of this article as customary international law". ${ }^{85}$ It is further argued that the Act does not simply represent an implementing legislature, but reflects the state practice of the United States of America. Despite the fact that the law mentioned makes no reference to the exercise of universal jurisdiction for the violation of common Article 3 , what matters in this context is the establishment of the state practice in relation

\footnotetext{
${ }^{79}$ Legal Memorandum on Universal Jurisdiction, AI 53/005/2001 Chapter 3 http://web.amnesty.org/ web/web.nsf/pages/legal_memorandum (accessed 12.03.2003).

${ }^{80}$ Loi du Juin 16, 1993 relative à la répression des violations graves du droit international humanitaire, (avec les amendements de 10 février 1999) http://www.worldpolicy.org/globalrights/treaties/ Belgique-loi.html (accessed 08.03.2003).

81 Ibid.

${ }^{82}$ Graditzky, n. 2, at 39.

${ }^{83}$ Spanish Criminal Code of 23 November 1995, Articles 608-614, http://www.universaljurisdiction. info/index/Laws/Law_Summaries/80179,79779 (accessed 12.03.2003).

${ }^{84}$ J. Aldykiewsz, "Authority to court-martial non-U.S. military personnel for serious violations of international humanitarian law committed during internal armed conflicts", 167 Mil.L.Rev. (Lexisnexis), f. 150.

85 Ibid.
} 
to criminalization of Article 3, i.e., the prosecution of the perpetrators for the violation of the provision of this article.

The Swiss Military Penal Code of 13 June 1927, with the recent amendments, also provides for universal jurisdiction for violations of the law applicable in internal conflicts. Article 2 (9) of the Code provides that the civilians who have committed crimes against the law of nations in the course of armed conflict can be prosecuted under the military penal code. ${ }^{86}$

The Netherlands Wartime Criminal Act provides jurisdiction over violations of the laws and customs of war including Geneva Conventions and Protocol I. Article 8 of this law criminalizes all violations of the laws and customs of war. It is established that the reach of the article is limited neither to grave breaches of the Geneva Conventions nor to armed conflicts of an international character. ${ }^{87}$ Article 1, paragraph 3, of the Wartime Act indicates that the term "war" includes civil wars. ${ }^{88}$

Other examples include the Nicaraguan Penal Code, which provides universal jurisdiction over violations of international humanitarian law regardless of the character of the conflict, and the Irish Geneva Convention Act, criminalizing violations of the Geneva Conventions including Article 3. ${ }^{89}$ Many other states pursue the line of the criminalization of international humanitarian law. Their respective legislatures address violations of the law applicable to conflicts of both an international and a non-international character, but a weakness may be seen in the failure of these examples of legislation to provide pure universal jurisdiction; conditions are attached in order to make them applicable extra-territorially. This is true, for example, with regard to the Portuguese Penal Code, which extends jurisdiction beyond its territory and [beyond its treatment of] non-nationals only, for instance, in the event of an international treaty provision imposing such a jurisdiction. ${ }^{90}$ It should be noted here that the nature of the jurisdiction authorized by national legislations is permissive as there is no requirement deriving from any binding treaty. Rather, it is a conviction of the states that the fact that Article 3 lacks an enforcement mechanism should be understood to be tantamount to a crime giving rise to universal permissive jurisdiction.

\subsubsection{Judicial decisions}

Some points of interest were raised in the course of the torts claim brought in the case of Kadic v. Karadzic by Bosnian victims under the US Alien Tort Act against Radovan Karadzic. The complainants alleged that they are victims of acts of rape,

\footnotetext{
${ }^{86}$ Swiss Military Penal Code of 13 June 1927, Art.2, http://www.admin.ch/ch/f/rs/321_0/index.htmlh (accessed 12.03.2003).

${ }^{87}$ J. Kleffner "Jurisdiction over genocide, crimes against humanity, war crimes, torture and terrorism in the Netherlands", to be published in A. Cassese and M. Delmas-Marty (eds.), Crimes internacionaux et jurisdiction nationals: Étude comparée, Presses Universitaire de France, 2002, 8 http:// www1.jur.uva.nl/acil/jann_kleffner1.PDF (accessed 12.03.2003).

${ }^{88}$ Ibid., 10

${ }^{89}$ Graditzky, n. 2, at 43.

90 Ibid.
} 
forced prostitution, torture, summary executions, etc. The US Courts of Appeal for the Second Circuit determined that the alleged violations constitute violations of the law of nations. When considering the alleged crimes within the scope of war crimes, the court examined the context of common Article 3 confirming the existence of individual criminal responsibility, referring to the judgement of the post-WWII Military Tribunals. ${ }^{91}$ To quote the latter, "the court seemed convinced that the notion of war crimes together with universal jurisdiction also covered certain violations of the law applicable in non-international conflicts". ${ }^{92}$

On 30 April 1997, the Swiss Military Tribunal found the former Rwandan mayor of Mushubati guilty of committing war crimes as well as of a violation of common Article 3 of the Geneva Conventions, on the basis of the Swiss Military Penal Code. It is determined that this decision was the first conviction in Switzerland to provide universal jurisdiction for war crimes in the context of non-international conflict. ${ }^{93}$

The case of Knezevic is an interesting precedent of application of the norms of the Netherlands legislation that was mentioned earlier. The magistrate of Arnhem had to establish a preliminary judicial enquiry requested by the public prosecutor in respect of war crimes committed in the territory of the former Yugoslavia in 1992. ${ }^{94}$ In this respect Knezevic was suspected of implication in the commission of a number of war crimes. The public prosecutor qualified the conflict as a non-international conflict and described the alleged offences as violations of common Article 3 of the Geneva Conventions of 1949. The magistrate held that the Netherlands had no jurisdiction and, soon after, an appeal was brought to the District Court (Military Division). The District Court found that the Dutch courts did indeed have the authority to try the case and that the alleged offences if proved would constitute violations of common Article 3. The court justified the existence of jurisdiction on the basis of Article 1 of the Wartime Criminal Act, section 1 of which provides for the prosecution of the crimes committed in armed conflicts, including civil wars, and section 3 providing for the universal jurisdiction. ${ }^{95}$

The Knezevic case is noteworthy since the District Court went through a very detailed examination of the Wartime Act provisions relating to the jurisdiction. In the second appeal, the Supreme Court returned to the issue of jurisdiction and came to the conclusion that section 3 of the Wartime Act expressly gives jurisdiction over war crimes irrespective of where and by whom they have been committed. ${ }^{96}$

The evaluation of whether each and every element of the rule is in compliance with the general requirements of customary law is complex. Thus, the task of conducting the work within the borders of the issues at stake forces one to omit a detailed examination of all the aspects of the customary nature of the rule, such as consistency, repetition, etc. The Appeals Chamber stated that reliance must be put upon opinio

91 Kadic v. Karadzic, 70 F. $3^{\text {d }} 232$ ( $2^{\text {nd }}$ Cir. 1995), Federal Reporter, at 243.

92 Graditzky, n. 2, at 44.

93 Legal Memorandum, n. 79.

94 J. Kleffner, n. 87, at 9.

95 Ibid., 11.

${ }^{96}$ Ibid., 13. 
juris due to an insufficiency of state practice, yet military manuals, state legislature and judicial decisions are indicative of existing state practice. Even though military manuals address only the conduct of armed forces, existing domestic legislations not only criminalize breaches of Article 3, but provide jurisdiction on the basis of the universality principle; furthermore, the judicial decisions provide evidence that the system in fact operates, hence: "All of these factors (i.e., opinio juris and state practice) confirm that international law imposes criminal liability for serious violations of common Article 3, as supplemented by other general principles and rules on the protection of victims of internal armed conflict". ${ }^{97}$

By enforcing relevant laws, states acknowledge that crimes committed in the context of internal conflicts are subject to universal reach whatever their nature, and that the form of the jurisdiction exercised is permissive, as there is no provision under conventional international law requiring states to prosecute perpetrators of internal conflicts regardless of any jurisdictional links, i.e., states would not be in breach of their obligations under international law.

\section{THE ROLE OF THE ROME STATUTE OF INTERNATIONAL CRIMINAL COURT IN THE CRIMINALIZATION OF COMMON ARTICLE 3}

The establishment of the International Criminal Court is not a result of the efforts of recent years: in fact, the process dates back to the era of the League of Nations, succeeded by the United Nations. The International Law Commission was the body put in charge of formulating the draft statute for the ICC. ${ }^{98}$ The political atmosphere in the Cold War period impeded effective work on the draft statute; the work was resumed in 1989. The years following the end of the Cold War were promising in terms of consensus and mutual understanding reigned between the former opponents. However, the emergence of new conflicts forced the world community to respond to large-scale human rights violations in the former Yugoslavia and in Rwanda through the creation of ad hoc tribunals.

Their establishment had a constructive impact. They "provided a final spur to the emergence of the ICC, an organ of global reach and thus potentially able to respond to violations occurring everywhere", ${ }^{99}$ neither temporally nor geographically limited. In 1994, subsequent to the submission of the Draft Statute of International Criminal Court to its Forty-Ninth session, the General Assembly set up a Preparatory Committee on the Establishment of the ICC which worked until the Diplomatic Conference at Rome of 15 June-17 July 1996 that in turn led to the adoption of the Rome Statute for the International Criminal Court. ${ }^{100}$

\footnotetext{
97 Prosecutor v. Tadic, n. 38, para. 134.

98 A. Cassese, P. Gaeta and J.R.W.D. Jones, The Rome Statute of the International Criminal Court: Commentary, Oxford University Press, 2002, at 6.

99 Ibid., 16.

100 Ibid.
} 
The first permanent international court has jurisdiction over genocide, crimes against humanity, war crimes and crimes of aggression. ${ }^{101}$ Even though the reach of the ICC is universal, its jurisdiction is not so, with the exception of those referrals of the Security Council that are based on the theory of universality. ${ }^{102}$ This fact by no means undermines the right or in some cases the duty of states to exercise their universal jurisdiction over international crimes. In affirmation of the latter, the preamble of the Rome Statute recalls "the duty of every state to exercise its criminal jurisdiction over those responsible for international crimes" and emphasizes that the International Criminal Court is complementary to national criminal jurisdiction. ${ }^{103}$ The Rome Statute is the first international treaty criminalizing serious violations of common Article 3, including this in the category of war crimes and thus prescribing individual criminal responsibility. The question of prior criminalization of Article 3 in the International Criminal Tribunal for the Rwanda Statute cannot be raised since the latter was established by a Security Council resolution under Chapter VII of the United Nations Charter.

Article 8, section 2 (c), of the Rome Statute of International Criminal Court includes in "war crimes" provisions serious violations of common Article 3 and other serious violations of the laws and customs of war applicable in non-international armed conflicts. The context of the provisions concerning Article 3 is analogous to the prohibitions listed in Article 3 itself.

It is argued that prior to the adoption of International Criminal Court Statute, only few countries would exercise universal jurisdiction over crimes committed in internal conflicts, as there were no treaty provisions authorizing such exercise. ${ }^{104}$ Further, it is suggested that the states should avail themselves of the opportunity to review their respective legislations and ensure that their courts are able to exercise universal jurisdiction over the crimes listed in the ICC Statute. ${ }^{105}$ Meron showed his recognition of this idea when he stated that the International Criminal Court "may thus become a model for national laws to be enforced under the principle of universality". 106

Thus, the basic implication of the Rome Statute of International Criminal Court in relation to the serious violations of common Article 3 is in fact that the adoption of the Rome Statute is an "authoritative and largely customary statement of international humanitarian and criminal law". ${ }^{107}$ Indeed, the reflection of Article 3 in the Rome Statute represents the finalization of the criminalization of the law applicable in internal conflicts under international customary law; in particular, the inclusion of the violation of common Article 3 into the category of war crimes in article 8

\footnotetext{
101 Rome Statute, n. 45, article 5.

102 Bassiokuni, n. 1.

103 Rome Statute, n. 45.

104 Y. Iwasawa, "Final report on the exercise of universal jurisdiction in respect of gross human rights offences", ILA report of $69^{\text {th }}$ session in London (2000), at 12.

105 Ibid.

106 Meron, Epilogue, n. 44, at 305.

107 Ibid.
} 
of the Statute evidences this statement. The International Criminal Court does not give rise to universal jurisdiction, and according to Article 1 of the Rome Statute it is complementary to national courts. However, once again it should be stressed that its significance is concluded in its representation of an "authoritative and customary statement of the international humanitarian law". As a consequence such a statement determines that the violation of common Article 3 is a crime under international customary law and that this in turn gives rise to universal permissive jurisdiction.

\section{CONCLUSION}

Thus, it is no longer incongruous that the international community regards serious breaches of common Article 3 as acts leading to individual criminal responsibility, and as crimes of universal concern and subject to universal condemnation. The consideration of opinio juris and more significantly, state practice, evidence the emergence of a customary rule criminalizing violations of Article 3 . The latter is supported by the adoption of the ICC Statute. Despite the fact that the jurisdiction of the International Criminal Court is not universal, it reflects the current position of states on the subject matter and constitutes a significant development in determining breaches of Article 3 as war crimes.

As a consequence, in the absence of a legally binding treaty provision, customary international law becomes the basis for the application of universal permissive jurisdiction over serious violations of Article 3. State sovereignty cannot constitute a barrier to the non-addressing of serious violations of the minimum humanitarian standards set in Article 3. Crimes remain crimes regardless of the context of the conflict. Recent developments in this sphere have prompted the assertion that serious breaches of common Article 3 lead to universal jurisdiction; at present, though, the jurisdiction is only permissive, until a relevant treaty provision requiring mandatory universal jurisdiction is adopted. 